Chapter 15

\title{
Potential Role of Parkia biglobosa in the Management and Treatment of Cardiovascular Diseases
}

\author{
O.B.L. Alinde, A.J. Esterhuyse and O.O. Oguntibeju \\ Additional information is available at the end of the chapter
}

http://dx.doi.org/10.5772/57229

\section{Introduction}

Non-communicable diseases (NCD), also known as chronic diseases represent one of the most serious health challenges of the 21st century. According to the World Health Organisation (WHO), global mortality due to NCD is projected to reach 55 million of deaths in the next 20 years, with 25 million of death caused by cardiovascular diseases (CVD) [1-3]. This is drawing a particular attention to the importance of intensifying research in the area aiming at fighting CVD through prevention and treatment. In a recent report of the WHO, CVD already accounted for $48 \%$ of NCD deaths [1]. Additionally, hypertension has been estimated to be the major risk factor for CVD morbidity and mortality, causing $51 \%$ of stroke deaths and $45 \%$ of coronary heart diseases deaths $[1,3]$. Furthermore, CVD is increasing in the low- and middleincome with Sub-Saharan African countries recording the highest rate of hypertension [1-3]. It has been observed that these countries record an increase in the overall rate of hypertension mainly because of severe financial constraints for its management and control $[1,4]$.

With the prevalence of hypertension in the world's death rate, new approaches to investigate the treatment and management of this disease are highly in demand in order to reduce the overall rate of adult mortality from CVD. Quest for solutions has open doors to research in the field of alternative and complementary medicine as an effective, safe, simple and inexpensive strategy. Medicinal plants and fruits and vegetables are reputed for their excellent healthenhancing bioactive micronutrients, their cost-effectiveness and their widespread bioavailability [5-9]. While some medicinal plants have been investigated in hypertension research, many remain a mystery [5-9]. Therefore, the interest of this review is to summarize the findings of recent studies on the potential cardioprotective effect of Parkia biglobosa, a locally available medicinal West African plant that has been reported to display anti-inflammatory, antimicrobial, antioxidant, anti-cancer and hypotensive activities in its diverse parts [10-14]. In this 
chapter, a brief explanatory overview of hypertension and its implication in CVD will be given followed by a summary of potential ability of Parkia biglobosa to modulate health, especially CVD.

\section{Hypertension}

Hypertension, also known as raised blood pressure (BP), is a chronic medical condition and a slow progressive disease defined by a mean systolic BP (SBP) of at least $140 \mathrm{~mm} \mathrm{Hg}$ and/or a diastolic BP (DBP) of at least $90 \mathrm{~mm} \mathrm{Hg}[4,15-16]$. In the USA, the seventh report of the Joint National Committee (JNC 7) on Prevention, Detection, Evaluation, and Treatment of High Blood Pressure has classified measured BP into different schemes and introduced a new classification referred to as "Prehypertension" [15]. Prehypertension was not defined as a disease-state but represented BP measurements of individuals at high risk of developing hypertension (Table 1). Hypertension has been classified into primary hypertension or essential hypertension (EH) and secondary hypertension (SH). They have respectively unknown and known aetiology.

\begin{tabular}{lll}
\hline \multirow{2}{*}{ JNC 7 category } & \multicolumn{1}{l}{ Blood pressure $\mathbf{( m m} \mathbf{~ H g})$} & \\
\cline { 2 - 3 } \cline { 2 - 3 } Normal & SBP & DBP \\
\hline Prehypertension & lower than 120 & lower than 80 \\
\hline Hypertension & 120 to 139 & 80 to 89 \\
\hline Stage 1 & 140 or higher & 90 or higher \\
\hline Stage 2 & 140 to 159 & 90 to 99 \\
\hline
\end{tabular}

Table 1. JNC 7 Classification of blood pressure $[4,15]$

Hypertension is a major public health problem responsible for $51 \%$ of stroke deaths and $45 \%$ of coronary heart diseases deaths [1, 3]. It represents the leading global risk factor of mortality, about $12.8 \%$ of global death [3] and is also reported to affects both man and woman [17]. Additionally, the prevalence of hypertension is reported to increase with body weight and advancing age $[2,15-16,18]$. Conversely, hypertension in children has been reported, especially, in overweight and obese children [19]. It has been observed that Black men and women have the highest prevalence of total hypertension [15-16]. Furthermore, while the large proportion of the population suffers from $\mathrm{EH}(90-95 \%)$, only 5-10\% among the cases suffers from SH [20-24]. It has been reported that most individuals have an uncontrolled hypertension because the disease is predominantly a "silent" disease which is asymptomatic [17]. Epidemiological studies estimated that in the United States, one in five adult remains unaware of his diseased-state [16]. Nonetheless, with the rise of campaign aimed at increasing hypertension awareness and treatment, the prevalence of uncontrolled hypertension is declining in developed countries, 
when compared to developing countries [16, 18]. Actually, the low- and middle-income countries, especially Sub-Saharan African countries record an increase in the overall rate of hypertension mostly because of the severe financial constraints, limited set of health services, low access to facilities and low level of awareness, control, treatment campaigns [4].

\subsection{Aetiology of essential hypertension}

The aetiology of EH remains a mystery. Even though, EH is the commonest form of hypertension ( $90 \%$ - 95\% of all cases), the underlying defects triggering its onset are not known. This explains the difficulty in finding a definite cure. It has been theoretically proposed (Mosaic Theory of Dr Irvine Page) that the aetiology of EH is multifactorial with genetic, environmental, anatomical, adaptive, neural, endocrine, humoral, haemodynamic risk factors and that those different risk factors interlink together to cause hypertension [25-27]. Some of these risk factors are described below:

\subsubsection{Environmental risk factors}

Various dietary habits and unhealthy lifestyle have also been identified to play a major role in the pathogenesis of hypertension such as:

- Pollutants

- Use of tobacco,

- Chronic consumption of alcohol,

- Lack of weight maintenance (sport inactivity),

- Adoption of diets characterised by high intake of glucose, high intake of saturated fat and cholesterol, high intake of salt (exceeding 5.8 grams daily) [6, 28].

The consequences of this adopted lifestyle give the rise to metabolic and physiological alterations which mediate the pathogenesis of hypertension and promotes other deleterious conditions such as hyperglycaemia (principal characteristic of diabetes) and hyperlipidaemia (principal characteristic of obesity) [29].

\subsubsection{Hereditary risk factors}

Genetic factors are thought to play a prominent role in the development of essential hypertension, especially genetic abnormalities of the baroreceptor system. However, the genes for hypertension have not yet been identified.

The baroreceptor system consists of nerves ending receptors sensitive to stretch, pulse rate and pressure changes of the blood vessels [30]. They are present on the wall of large arteries such as the aortic arch and the carotid sinus (Figure 1). They stand as the first line of neural control system over blood pressure fluctuation and constitute a short term regulation of BP [31-33]. With a significant change in $\mathrm{BP}$, baroreceptors transmit impulses to central nervous system (CNS) to activate a "feedback" mechanism from autonomous nervous system called barorecep- 
tor reflex or baroreflex. The baroreceptor autonomous reflex restores the BP to normal values [30-33]. It has been reported that that lack of baroreflex sensitivity is associated with the presence of a family history of hypertension $[32,34]$. This shows that hypertension could be initiated from specific hereditary genetic abnormalities involving baroreceptors sensitivity [32, 34].

In addition, hereditary genetic abnormalities of the neuroendocrine regulation of baroreceptors have similarly been recognised as predictors of EH. For instance, studies have related overexpression of Chromogranin A ( $\mathrm{Cg} \mathrm{A}$ ) in plasma, adrenal medulla and sympathetic neurons to essential hypertension in both clinical and experimental models [25, 35]. Similarly, $\mathrm{Cg}$ A loci genetic polymorphism was related to hypertension [36]. Chromogranin A is a prohormone stored and released with catecholamine (epinephrine, norepinephrine and dopamine) by exocytosis [37-38]. It is believed that $\mathrm{Cg}$ A influence sympathetic tone since it is a prohormone for active peptides with regulatory properties, namely vasostatin, pancreastastin and catestatin [37, 39]. Catestatin exhibits catecholamine release-inhibitory function and may function as a vasodilator [40-41]. Decreased circulating level of catestatin has been related to $\mathrm{EH}$ because it increases adrenergic pressor response by no longer exerting antagonism to neuronal nicotinic acetylcholine receptor [40-41].

Several genetic factors can affect the renin-angiotensin-aldosterone system and indirectly result in hereditary hypertension. For instance, deficient formation of kinin components (proteins that act locally to induce vasodilatation) in the body may also lead to hypertension and development of CVD. Renal kinin-kallikrein system helps to excrete excess sodium from the biological system [42]. Therefore, a reduction in renal expression of kinin-kalllikrein system can also be identified as a genetic factor for hypertension as a result of accumulation of sodium in the body. Consequently, diminished urinary kallikrein (sub-group of serine protease) excretion could represent a genetic marker of hereditary hypertension [42-43].

\subsubsection{Haemodynamic, endocrine, neural, anatomical risk factors}

The cardiovascular system ensures the supply of blood to all organs and tissues via distensible blood vessels such as arteries, veins and capillaries of the circulatory system (peripheral and pulmonary). Blood pressure represents the force with which the blood pushes against the wall of the arteries. At physiological level, factors such as blood volume, cardiac output, diameter of artery lumen, and elasticity of artery determine BP [44-45]. In addition, different systems contribute to the short-term and long-term regulation of BP such as:

- The nervous system baroreceptor reflex [46].

- The humoral secretion of vasoconstrictors and vasodilators substances such as acetylcholine, atropine [47].

- The kidneys regulation of BP via renal body fluid feedback, namely the renin-angiotensinaldosterone system and the pressure natriuresis [31, 43].

Therefore, any molecular and physiological dysfunction affecting the regulation of BP can be associated with the pathogenesis of hypertension such as dysfunctions of the renin angiotensin system (RAS), dysfunctions in electrolytes homeostasis, dysfunctions of the endocrine system 
and increased arterial resistance $[25,48]$. For example, the renin angiotensin system (RAS) is a central system involved in the regulation of BP and electrolytes homeostasis. Briefly, with a decrease in BP, kidneys prorenin are converted into active renin. Active renin cleaves the hepatic precursor protein angiotensinogen into the inactive angiotensin I (Ang I) [43, 49]. Then, the angiotensin converting enzyme (ACE) hydrolyses two principal molecules. Firstly, ACE cleaves the inactive Ang I to give active vasoconstrictor hormone Angiotensin II (Ang II). Angiotensin II, not only increases BP by constricting blood vessels but also causes the adrenal gland to release aldosterone, a hormone which increase BP through renal retention of sodium and water (increase of blood volume) and decrease excretion of potassium [42-43, 49]. Secondly, ACE which is a kininase II interact with the kinin-kalllikrein system and inactivate the vasodilator bradikinin by releasing pentapeptide Arg-Pro-Pro-gly-Pheo and tripeptide Ser-Pro-Phe fragments [42]. Therefore, failure to regulate the activated RAS at different level could lead to hypertension. Another example of system dysfunction involved the failure to regulate the increased activity of norepinephrine [48].

\subsection{Aetiology of secondary hypertension}

The aetiology of $\mathrm{SH}$ has been often identified with an underlying illness which indirectly increases BP. It has also been demonstrated that $\mathrm{SH}$ can emerge from drugs intake and health conditions such as pregnancy [15, 20, 50-52] (Table 2). Therefore, the treatment of SH is associated along with the treatment of the identified underlying factors.

\begin{tabular}{lll}
\hline Causes & Examples & \\
\hline Renal diseases & RENAL PARENCHYMAL DISEASES: & RENOVASCULAR DISEASES/RENAL ARTERY \\
& $\bullet$ Glomerulonephritis & STENOSIS \\
& $\bullet$ Polycystic kidney diseases & $\bullet$ Atherosclerotic renal artery diseases \\
& $\bullet$ Diabetic nephropathy & $\bullet$ Fibromuscular dysplasia \\
& $\bullet$ Hydronephrosis & •Renal artery embolism \\
& $\bullet$ Chronic kidney disease (CKD) & •Arteriovenous malformation of the renal \\
& $\bullet$ artery \\
\hline Vascular diseases & $\bullet$ Aortoarteritis & \\
\hline Endocrinal and metabolic & $\bullet$ Primary aldosteronism (Conn Syndrome), \\
diseases & $\bullet$ Primary sodium retention (Liddle's Syndrome) \\
& $\bullet$ Cushing syndrome & \\
& $\bullet$ Pheochromocytoma & \\
\hline Neurological diseases & $\bullet$ Brain tumours \\
\hline Drugs & $\bullet$ Encephalitis \\
\hline & $\bullet$ Oral contraceptive pills \\
& $\bullet$ Non-steroidal anti-inflammatory medications \\
& $\bullet$ Drug Abuse (Cocaine, Alcohol) & \\
\hline
\end{tabular}

Table 2. Causes of secondary hypertension [52] 


\subsection{Molecular mechanisms involved in the pathogenesis of hypertension}

Previous studies have shown the involvement of excessive reactive oxygen species (ROS) in the pathophysiology of CVD [53-56]. At a molecular level, oxidative stress (Oxs) has been identified to have major implication in the development of clinical and experimental hypertension [57-59]. It was demonstrated that chronic glutathione depletion induced severe elevation of arterial BP [60]. The lack of endogenous antioxidant enzymes worsens oxidative stress and can indirectly promote the risk of hypertension. For example, a recent research supports the influence of genetic polymorphism of antioxidant enzymes in increasing the risk of hypertension [61]. Likewise, [62] in Taiwan demonstrated that manganese superoxide dismutase (MnSOD) polymorphism significantly increased the risk of hypertension.

Inflammation and lipid peroxidation are central to the development of multiple CVD and are mediated by a variety of cell types including macrophages, lymphocytes, endothelial cells and vascular smooth muscles cells [63-65]. The multiple cell types which participate in vascular inflammation produce various pro- and anti-inflammatory cytokines and specific membrane receptors allowing them to transmit their effects to the cells. Studies place a strong emphasis on the role of oxidative stress in the pathophysiology of hypertension through promotion of chronic inflammation [66]. In fact, the rise of Oxs in the vasculature decreased bioavailability of nitric oxide (NO). This leads to endothelial dysfunction due to the loss of vasodilation of blood vessels [58, 67-69]. In addition, oxidative stress coupled with hyperlipidaemia and hypercholesterolemia in the vasculature gives rise to atherosclerosis by oxidation of lipids in the vessels. Atherosclerosis is an inflammatory disease leading to increased arteriolar resistance and increased large artery stiffness and obstruction of blood vessels and subsequent ischemia [70].

\subsection{Consequences of hypertension}

The continuous high pressure exerted on the arteries wall causes long term damages to both blood vessels and organs. In fact, when hypertension is not timely acknowledged and controlled, damages to organs can become severe and fatal [15, 51-52]. Numerous complications resulting from hypertension are illustrated in Table 3.

\subsection{Orthodox therapeutic approaches to managing/treating hypertension}

Although, no definite cure has been found to treat essential hypertension, many approaches have been used to manage and control its incidence; in particular lifestyle changes and the use of medications. Lowering salt and alcohol intake, lowering consumption of saturated fats and cholesterol rich food and practising regular exercise are important steps taken towards control of BP [17]. However, these steps are often associated with prescription of anti-hypertensive medication. Many types of anti-hypertensive drugs have been developed over the years such as diuretics, ACE inhibitors, angiotensin II receptorblocker, calcium channel blockers, alpha and beta blockers [71-73]. Even though a wide variety of anti-hypertensive drugs are effective to control and manage hypertension, they are not without considerable side effects [74-75]. Additionally, the cost of medication is not 


\begin{tabular}{|c|c|c|}
\hline End Organ & CVD Damages & $\begin{array}{l}\text { Complications/ } \\
\text { Consequences }\end{array}$ \\
\hline Heart & $\begin{array}{l}\text {-Acute coronary syndrome, } \\
\text {-Ischaemic heart diseases } \\
\text {-Myocardial infarction, } \\
\text {-Atrial fibrillation, } \\
\text {-Arrhythmias, } \\
\text { - Coronary artery disease, } \\
\text { - Left ventricular hypertrophy leading to chronic heart failure }\end{array}$ & Sudden death \\
\hline Brain & $\begin{array}{l}\text { - Constant headaches } \\
\text {-Stroke } \\
\text {-Neurological damages (memory loss, dementia) } \\
\text {-Disability (paralysis) }\end{array}$ & Sudden death \\
\hline Kidney & $\begin{array}{l}\text {-Renovascular dysfunction, } \\
\text {-Chronic kidney failure, } \\
\text {-End stage renal diseases (ESDR) }\end{array}$ & Death \\
\hline Eyes & Hypertensive retinopathy & Blindness \\
\hline Vascular system & $\begin{array}{l}\text {-Atherosclerosis } \\
\text {-Arterial resistance } \\
\text {-Aneurysm } \\
\text { - Embolus and thrombo-embolus } \\
\text {-All the above }\end{array}$ & $\begin{array}{l}\text { Brain, heart, kidney, } \\
\text { eyes damages Death }\end{array}$ \\
\hline
\end{tabular}

Table 3. End organs damages related to hypertension

always affordable for the majority of the population, especially in developing countries, since managing hypertension represents a lifelong financial investment. Henceforth, research is now turning to alternative and complementary medicine. Many reports support the concept that natural or dietary supplementation can be used to develop effective, safe, simple and inexpensive antihypertensive treatment $[6,28]$. As a result, many researches are currently directed towards a search for useful bioactive compounds in medicinal plants as a new strategy for the treatment and management of hypertension $[5,8,49,76]$.

\subsection{Alternative therapeutic approach to hypertension}

Deeper exploration of phytochemicals found in medicinal plants is used as an approach to discover potential prophylactic and therapeutic agents in cardio protection [7-9]. Medicinal plants can be used to develop effective, safe, simple and inexpensive antihypertensive treatment since they are reputed for their excellent health-enhancing bioactive micronutrients, their cost-effectiveness and their widespread bioavailability [7, 77-78]. As a result, research is currently directed towards discovering useful bioactive compounds in medicinal plants that could be used as new strategies for treatment and management of hypertension $[5,8,49,76]$. 


\section{Parkia biglobosa}

\subsection{Brief description}

Parkia biglobosa, also called the African Locust Bean tree is a multipurpose tree indigenous to the tropical regions of West Africa. Parkia biglobosa belongs to the family Mimosaceae (Leguminosae - Mimosoideae) [79-evidences. Therefore, studies of the]. Parkia biglobosa is a widespread savannah tree used for nutritional and medicinal purposes [7, 81, 71]. The matured tree can grow up to $30 \mathrm{~m}$ in height with a crown large of low branches. The bark is thick and fissured with a grey to brown colour. The leaves are alternate, dark green and bipinnate. The leaves are about $8-30 \mathrm{~mm} \times 1.5-8 \mathrm{~mm}$ in size with 13-60 pairs of leaflets held on a long rachis [82].

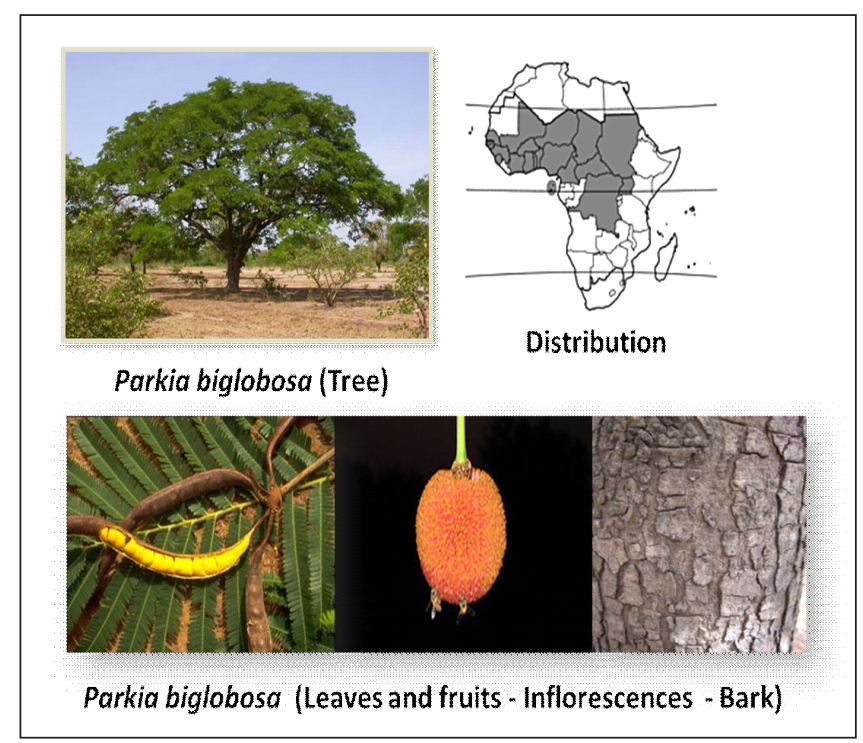

Figure 1. Parkia biglobosa [83]

The analysis of the phytochemicals present in Parkia biglobosa revealed the presence of alkaloid, flavonoids, tannins, saponins, cardiac glycosides, sterols, resins and terpenes (Table 4) [80, 84-85].

\subsection{Potential health benefits of Parkia biglobosa}

For a long time, native populations of West Africa have been using different parts of Parkia biglobosa to meet their nutritional and basic health care needs. In different countries, Parkia biglobosa has been used as a multipurpose plant in the therapy of a variety of diseases including 


\begin{tabular}{|c|c|c|c|c|c|}
\hline & Plant & & big & & \multirow{2}{*}{ REFERENCES } \\
\hline & Extracts $(\mathrm{W}, \mathrm{P}, \mathrm{C}, \mathrm{M})$ & \multicolumn{3}{|c|}{ Leaf extracts Bark extracts Root extracts } & \\
\hline \multirow{8}{*}{ 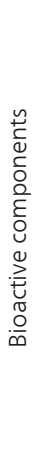 } & Saponins & + & + & + & {$[85,86,87]$} \\
\hline & Cardiac Glycosides & + & + & + & {$[85,87]$} \\
\hline & Tannins & + & + & + & {$[85,86,87]$} \\
\hline & $\begin{array}{l}\text { Flavonoids (Anthocyanins, flavonones, } \\
\text { coumarins, catechins) }\end{array}$ & + & + & + & {$[85,86,87]$} \\
\hline & Alkaloids & - & + & + & {$[85,87]$} \\
\hline & Resins & + & + & + & {$[85]$} \\
\hline & Carbohydrates & + & + & + & {$[85]$} \\
\hline & Sterols and Terpenoids & + & + & + & {$[86,87,88]$} \\
\hline
\end{tabular}

Abbreviations: W: water, P: petroleum ester, C: Chloroform, M: Methanol, +: Present, - : Absent.

Table 4. Brief summary of the bioactive components in Parkia biglobosa

hypertension. A summary of traditional medicine practices from different West African countries is illustrated in Table 5.

The fact that repetitive information was obtained from traditional healers and population from diverse regions and countries indicated the need to scientifically authenticate these folkloric evidence. Therefore, studies of the extracts of Parkia biglobosa have been conducted and experimental and clinical data are now recognizing the health benefits attributed to Parkia biglobosa in its diverse parts. Parkia biglobosa bark extracts have been identified to have significant anti-inflammatory, analgesic, antibacterial and anti-helminthic activities. For example, the analgesic and anti-inflammatory property of Parkia biglobosa bark extract in the management of toothache has been demonstrated [102]. The anti-venom activity of the bark extract against snake bites has also been reported [103]. In 2007, some clinical investigations described the antibacterial properties of Parkia biglobosa bark and root extracts against Staphylococcus aureus, Pseudomonas aeruginosa, Klebsiella pneumoniae, Escherichia coli, Shigella dysenteriae responsible for urinary tract and digestive system infections [84, 86, 104]. Additionally, Parkia biglobosa stem bark has been attributed anti-microbial effects against Bacillus subtilitis and was recommended as a natural preservative against pharmacological contaminations [85]. Parkia biglobosa leaf extract were described to exhibit anti-plasmodial activity against malaria [105]. Recently, antioxidant, anti-carcinogenic and anti-trypanosomic activities of the plant have been acknowledged [78, 97, 106-107].

\subsection{Potential benefits of Parkia biglobosa in the treatment of hypertension and CVD}

Previous investigations have indicated the hypotensive potential of Parkia biglobosa extracts. For example, it was reported that a methanolic seed extract decreased blood pressure in the 


\begin{tabular}{|c|c|c|c|}
\hline Countries & Used Parts & Traditional medicine practice & References \\
\hline \multirow{6}{*}{ Benin } & \multirow{6}{*}{ All parts } & $\begin{array}{l}\text { Treatment of digestive system diseases (diarrhoea, } \\
\text { dysentery, abdominal pain) }\end{array}$ & \multirow{6}{*}{ [89] } \\
\hline & & Treatment of diseases of the cardiovascular system & \\
\hline & & Treatment of injuries and burns & \\
\hline & & $\begin{array}{l}\text { Treatment of infectious diseases (shingles, malaria, } \\
\text { abscesses, yellow fever, scabies, measles, chicken-pox, } \\
\text { oedema, jaundice) }\end{array}$ & \\
\hline & & Treatment of paediatric pathologies & \\
\hline & & $\begin{array}{l}\text { Treatment of symptoms and syndromes: malaise, } \\
\text { tiredness, headaches, hip pain, ache, rheumatism, } \\
\text { elephantiasis, onset of paralysis }\end{array}$ & \\
\hline Burkina Faso & $\begin{array}{l}\text { Fermented seeds, } \\
\text { leaves, stem bark }\end{array}$ & $\begin{array}{l}\text { Treatment of oral infections: Gingivitis, toothache, } \\
\text { sores (tongues and lips) }\end{array}$ & {$[90]$} \\
\hline Ghana & $\begin{array}{l}\text { Leaves, stem bark, raw } \\
\text { fruit, fermented seed }\end{array}$ & Treatment of malaria, stomach ache & {$[77]$} \\
\hline Ivory coast & Stem bark & Treatment of malaria & [91] \\
\hline \multirow{3}{*}{ Mali } & Leaves & Wound healing & {$[92]$} \\
\hline & $\begin{array}{l}\text { Leaves, } \\
\text { stem bark }\end{array}$ & $\begin{array}{l}\text { Treatment of malaria, urinary tract infection and } \\
\text { internal wounds of pregnant women }\end{array}$ & [93] \\
\hline & Stem bark & Personal health, insect management & [94] \\
\hline \multirow{2}{*}{ Nigeria (North) } & Leaves & Treatment of inflammations & [95] \\
\hline & Stem bark & Treatment of diarrhoea & {$[96]$} \\
\hline \multirow{3}{*}{$\begin{array}{l}\text { Nigeria } \\
\text { (South West) }\end{array}$} & Stem bark & $\begin{array}{l}\text { Treatment of trypanosomiasis, fever, ulcer, wound } \\
\text { healing }\end{array}$ & {$[78,97]$} \\
\hline & Roots & $\begin{array}{c}\text { Treatment of hypertension, infertility, stomach ache, } \\
\text { sore eye, anti-poison }\end{array}$ & {$[98,99]$} \\
\hline & Leaves & $\begin{array}{l}\text { Treatment of stroke, leprosy, skin lesion, eye } \\
\text { infections }\end{array}$ & [99] \\
\hline $\begin{array}{l}\text { Nigeria } \\
\text { (South East) }\end{array}$ & Stem bark & Treatment of hypertension & [7] \\
\hline \multirow{2}{*}{ Togo } & Roots & Treatment of haemorrhoids, Diarrhoea & {$[100]$} \\
\hline & Stem bark & Cardioprotection & {$[101]$} \\
\hline
\end{tabular}

Table 5. West African folkloric use of Parkia biglobosa for the treatment of diseases

rat [10], an aqueous bark extract decreased blood pressure in rabbits [12] a hydroalcoholic bark extract of Parkia biglobosa caused vasorelaxation [13] and a methanolic leaf extract demonstrated hypotensive activities [14]. Hypercholesterolemia and hypertriglyceridemia are known risk 
factors associated with hypertension and CVD. The anti-hyperlipidaemia effect of the aqueous and methanolic extracts of Parkia biglobosa has been described to reduce hypercholesterolemia and hypertriglyceridemia in diabetic rats [11]. Therefore, Parkia biglobosa could offer protection against the development of coronary heart diseases in diabetics [11]. Recently, another study on the methanolic leaf extract of Parkia biglobosa also confirmed protection against doxorubicin-induced cardiotoxicity in rats [87]. In this study, scientists proposed that protection was offered through the antioxidant content and anti-inflammatory properties of the plant extract. Alternatively, it was proposed that protection against cardiotoxicity might have originated from the potential synergistic interactions among the plant phytochemicals. In fact, Parkia biglobosa has a rich composition of secondary metabolites which have been individually reported to possess excellent cardiovascular properties, namely:

- saponins (a vast group of glycosides) recently known for providing cardioprotective effects in experimental model [108],

- cardiac glycosides (group of steroidal glycosides) reported to act as cardiotonic agent [109],

- tannic acid (typical product containing hydrolysable tannins) known for its ability to reduce serum cholesterol and triglycerides [110-111],

- triterpenoids such as lupeol known to display antioxidant, anti-hypercholesterolemic and cardioprotective activities [112-113],

- catechins (flavan-3-ol compounds) reported to reduce atherosclerotic plaques formation in animal models [114],

- epicatechins known to reduce the risk of stroke and heart failure [115-116].

Furthermore, it was also reported that a leaf extract of Parkia biglobosa is a strong inducer of endothelium-dependent relaxations involving both NO and EDHF via a redox-sensitive mechanism [117]. Moreover, it was suggested that procyanidins fraction of the leaf extract exerted beneficial effects on the endothelial function by decreasing vascular tone and are the major inducers of the vasorelaxation [117].

In conclusion, many experimental and ethnoparmacological studies gave credence to the health enhancing-potential of Parkia biglobosa extracts in the treatment of disease conditions such as high blood pressure and CVD. However, there is still an important shortage of scientific evidence elucidating the exact mechanisms through which Parkia biglobosa extracts offer protection against hypertension. Therefore, further studies are warranted in CVD diseasedmodel in order to identify the main phytoconstituents involved in the hypotensive response. The mechanisms of action through which the plant extract offer protection against cardiotoxicity and hypertension should also be investigated. Furthermore, the indigenous population have not adopted standardised methods (the population continue to use uncontrolled dosages and in most instances, preparations of Parkia biglobosa extracts are stored in inappropriate conditions) on the medicinal use of the plant. Therefore, caution and care are still needed to be applied on the folkloric use of Parkia biglobosa. 


\section{Author details}

O.B.L. Alinde*, A.J. Esterhuyse and O.O. Oguntibeju

*Address all correspondence to: alindeb@cput.ac.za, lidwina785@gmail.com

Oxidative Stress Research Centre, Department of Biomedical Sciences, Faculty of Health \& Wellness Sciences, Cape Peninsula University of Technology, Bellville, South Africa

\section{References}

[1] Mathers C, Stevens G, Mascarenhas M. Global health risks: mortality and burden of disease attributable to selected major risks. World Health Organization; 2009.

[2] World Health Organisation (a). World Health Statistics 2012. World Health Organisation; 2012.

[3] World Health Organisation (b). World Health Statistics 2012: A snapshot of global health. World Health Organisation; 2012.

[4] Pires JE, Sebastião YV, Langa AJ, Nery SV. Hypertension in Northern Angola: prevalence, associated factors, awareness, treatment and control. BMC Public Health 2013; 13(1): 1-10.

[5] Somova L, Shode F, Ramnanan P, Nadar A. Antihypertensive, antiatherosclerotic and antioxidant activity of triterpenoids isolated from Olea europaea, subspecies Africana leaves. J Ethnopharmacol 2003; 84(2): 299-305.

[6] Bazzano LA. Dietary intake of fruit and vegetables and risk of diabetes mellitus and cardiovascular diseases. World Health Organisation; 2005.

[7] Gbolade A. Ethnobotanical study of plants used in treating hypertension in Edo State of Nigeria. J Ethnopharmacol 2012; 144: 1-10.

[8] Raji IA, Mugabo P, Obikeze K. Effect of Tulbaghia violacea on the blood pressure and heart rate in male spontaneously hypertensive Wistar rats. J Ethnopharmacol 2012; 140(1): 98-106.

[9] Boon C, Ng M, Choo Y, Mok S.. Super, Red Palm and Palm Oleins Improve the Blood Pressure, Heart Size, Aortic Media Thickness and Lipid Profile in Spontaneously Hypertensive Rats. PLoS One 2013; 8(2): e55908.

[10] Assane M, Baba Moussa R, Bassene E, Sere A. Antihypertensive action of Parkia biglobosa (Jacq) Benth seeds in the rat. Dakar Med 1993; 38(1): 49-54. 
[11] Odetola A, Akinloye O, Egunjobi C, Adekunle W, Ayoola A. Possible antidiabetic and antihyperlipidaemic effect of fermented Parkia biglobosa (jacq) extract in alloxaninduced diabetic rats. Clin Exp Pharmacol Physiol 2006; 33(9): 808-812.

[12] Kassi Y, Aka KJ, Abo KJ, Mea A, Bi SAN, Ehile EE. Effet antihypertensif d' un extrait aqueux d' écorce de tronc de Parkia biglobosa (mimosaceae) sur la pression artérielle de lapin. Sci. Nat 2008; 5(2): 133-143.

[13] Kane MO, Sarr M, Gueye PM, Ndiaye CAB, Diaw M, Ba A, Sar FB, Sall/Diallo A. Effets relaxants vasculaires d'un extrait hydroalcoolique d'écorce de Parkia biglobosa (mimosaceae). Science Lib Editions Mersenne 2009; 2 (090901).

[14] Olaleye TM, Komolafe K, Akindahunsi AA. Effects of methanolic leaf extract of Parkia biglobosa on some biochemical indices and hemodynamic parameters in rats. J Chem Pharm Res 2013; 5(1): 213-220.

[15] Chobanian AV, Bakris GL, Black HR, Cushman WC, Green LA, Izzo JL, Jones DW, Materson BJ, Oparil S, Wright JT. Seventh report of the joint national committee on prevention, detection, evaluation, and treatment of high blood pressure. Hypertension 2003; 42(6): 1206-1252.

[16] Olives C, Myerson R, Mokdad AH, Murray CJ, Lim SS. Prevalence, Awareness, Treatment, and Control of Hypertension in United States Counties, 2001-2009. PLoS One 2013; 8(4): e60308.

[17] Wilkins K, Campbell NR, Joffres MR, McAlister FA, Nichol M, Quach S, Johansen HL, Tremblay MS. Blood pressure in Canadian adults. Health Rep 2010; 21(1): 37-46.

[18] Atwood KM, Robitaille CJ, Reimer K, Dai S, Johansen HL, Smith MJ. Comparison of Diagnosed, Self-Reported, and Physically-Measured Hypertension in Canada. Can J Cardiol 2013; 29: 606-612.

[19] Lu X, Shi P, Luo C, Zhou Y, Yu H, Guo C, Wu F. Prevalence of hypertension in overweight and obese children from a large school-based population in Shanghai, China. BMC Public Health 2013; 13(1): 24.

[20] Danielson M \& Dammstrom B. The prevalence of secondary and curable hypertension. Acta Med Scand Suppl 1981; 209(1-6): 451-455.

[21] Sinclair AM, Isles CG, Brown I, Cameron H, Murray GD, Robertson JW. Secondary hypertension in a blood pressure clinic. Arch Intern Med 1987; 147(7): 1289-1293.

[22] Anderson Jr GH, Blakeman N, Streeten DH. The effect of age on prevalence of secondary forms of hypertension in 4429 consecutively referred patients. J Hypertens 1994; 12(5): 609-615.

[23] Omura M, Saito J, Yamaguchi K, Kakuta Y, Nishikawa T. Prospective study on the prevalence of secondary hypertension among hypertensive patients visiting a general outpatient clinic in Japan. Hypertens Res 2004; 27(3): 193-202. 
[24] Kearney PM, Whelton M, Reynolds K, Muntner P, Whelton PK, He J. Global burden of hypertension: analysis of worldwide data. Lancet 2005; 365(9455): 217-223.

[25] Friese RS, Altshuler AE, Zhang K, Miramontes-Gonzalez JP, Hightower CM, Jirout ML, Salem RM, Gayen JR, Mahapatra NR, Biswas N. MicroRNA-22 and promoter motif polymorphisms at the Chga locus in genetic hypertension: functional and therapeutic implications for gene expression and the pathogenesis of hypertension. $\mathrm{Hu}^{-}$ man Molecular Genetic 2013; 22(18): 3624-3640.

[26] Harrison DG. The Mosaic Theory revisited: common molecular mechanisms coordinating diverse organ and cellular events in hypertension. J Am Soc Hypertens 2013; $7(1): 68-74$.

[27] Tu W \& Pratt JH. A consideration of genetic mechanisms behind the development of hypertension in Blacks. Curr Hypertens Rep 2013; 15: 1-6.

[28] Thompkinson D, Bhavana V, Kanika P. Dietary approaches for management of cardio-vascular health-a review. J Food Sci Technol 2012; doi 10.1007/s13197-012-0661-8.

[29] Majane OH, Vengethasamy L, du Toit EF, Makaula S, Woodiwiss AJ, Norton GR. Dietary-induced obesity hastens the progression from concentric cardiac hypertrophy to pump dysfunction in spontaneously hypertensive rats. Hypertension 2009; 54(6): 1376-1383.

[30] Heesch CM. Reflexes that control cardiovascular function. Am J Physiol 1999; 277: S234-S243.

[31] Brown AM. Receptors under pressure. An update on baroreceptors. Circ Res 1980; 46(1): 1-10.

[32] Parmer RJ, Cervenka JH, Stone RA. Baroreflex sensitivity and heredity in essential hypertension. Circulation 1992; 85(2): 497-503.

[33] Balijepalli C. Blood Pressure Distribution in the German Population. PhD Thesis, University Duisburg-Essen; 2012.

[34] Jordan J, Biaggioni I. Genetic influences on human baroreflex regulation. Autonomic Neuroscience. J Basic Clin Physiol Pharmacol 2012; 172: 23-25.

[35] O'Connor DT. Catecholamine storage vesicle protein expression in genetic hypertension. Blood Press 1999; 8(5-6): 285-295.

[36] Salem RM, Cadman PE, Chen Y, Rao F, Wen G, Hamilton BA, Rana BK, Smith DW, Stridsberg M, Ward HJ. Chromogranin A polymorphisms are associated with hypertensive renal disease. Clin J Am Soc Nephrol 2008; 19(3): 600-614.

[37] O'Connor DT \& Bernstein KN. Radioimmunoassay of chromogranin A in plasma as a measure of exocytotic sympathoadrenal activity in normal subjects and patients with pheochromocytoma. N Engl J Med 1984; 311(12): 764-770. 
[38] O'Connor DT, Kailasam MT, Kennedy BP, Ziegler MG, Yanaihara N, Parmer RJ. Early decline in the catecholamine release-inhibitory peptide catestatin in humans at genetic risk of hypertension. J Clin Hypertens 2002; 20(7): 1335-1345.

[39] Helle K, Corti A, Metz-Boutigue M, Tota B. The endocrine role for chromogranin A: a prohormone for peptides with regulatory properties. Mol Cell 2007; 64(22): 2863-2886.

[40] Rao F, Wen G, Gayen JR, Das M, Vaingankar SM, Rana BK, Mahata M, Kennedy BP, Salem RM, Stridsberg M. Catecholamine release-inhibitory peptide catestatin (chromogranin a352-372): naturally occurring amino acid variant gly364ser causes profound changes in human autonomic activity and alters risk for hypertension. Circulation 2007; 115(17): 2271-2281.

[41] Fung MM, Salem RM, Mehtani P, Thomas B, Lu CF, Perez B, Rao F, Stridsberg M, Ziegler MG, Mahata SK. Direct vasoactive effects of the chromogranin A (CHGA) peptide catestatin in humans in vivo. Clin Exp Hypertens 2010; 32(5): 278-287.

[42] Sharma JN. The kinin system in hypertensive pathophysiology. Inflammopharmacology 2013; 21(1): 1-9.

[43] Douglas R, Ehlers M, Sturrock E. The anti-fibrotic peptide Ac-Sdkp: opportunities for ACE inhibitor design. Clin Exp Pharmacol Physiol 2013; 40(8):535-541.

[44] Bergel D. The static elastic properties of the arterial wall. Physiol J 1961; 156(3): 445-457.

[45] Folkow B. "Structural factor" in primary and secondary hypertension. Hypertension 1990 ; 16(1): 89-101.

[46] Grassi G, Cattaneo BM, Seravalle G, Lanfranchi A, Mancia G. Baroreflex control of sympathetic nerve activity in essential and secondary hypertension. Hypertension 1998; 31(1): 68-72.

[47] Luscher T \& Vanhoutte PM. Endothelium-dependent contractions to acetylcholine in the aorta of the spontaneously hypertensive rat. Hypertension 1986; 8(4): 344-348.

[48] Russell V, Allie S, Wiggins T. Increased noradrenergic activity in prefrontal cortex slices of an animal model for attention-deficit hyperactivity disorder-the spontaneously hypertensive rat. Behav Brain Res 2000; 117(1): 69-74.

[49] Fernandez-Musoles R, Salom JB, Martinez-Maqueda D, Lopez-Diez JJ, Recio I, Manzanares P. Antihypertensive effects of lactoferrin hydrolysates: inhibition of angiotensin-and endothelin-converting enzymes. Food Chem 2013; 139: 994-1000.

[50] Tanabe A, Naruse M, Naruse K, Hase M, Yoshimoto T, Tanaka M, Seki T, Demura R, Demura H. Left ventricular hypertrophy is more prominent in patients with primary aldosteronism than in patients with other types of secondary hypertension. Hypertens Res: Hypertens Res 1997; 20(2): 85-90. 
[51] Holmlund A, Holm G, Lind L. Severity of periodontal disease and number of remaining teeth are related to the prevalence of myocardial infarction and hypertension in a study based on 4,254 subjects. J Periodontol 2006; 77(7): 1173-1178.

[52] Garg N, Bhatia T, Jaiswal A. Approach to a case of Secondary Hypertension. Clinical Queries: Nephrology 2013; 2: 62-70.

[53] Hamilton CA, Miller WH, Al-Benna S, Brosnan MJ, Drummond RD, McBride MW, Dominiczak AF. Strategies to reduce oxidative stress in cardiovascular disease. Clin Sci 2004; 106(3): 219-234.

[54] Fortuno A, San Jose G, Moreno MU, Diez J, Zalba G. Oxidative stress and vascular remodelling. Exp Physiol 2005; 90(4): 457-462.

[55] Berk BC. Novel approaches to treat oxidative stress and cardiovascular diseases. Trans Am Clin Climatol Assoc 2007; 118: 209-214.

[56] Heistad DD, Wakisaka Y, Miller J, Chu Y, Pena-Silva R. Novel aspects of oxidative stress in cardiovascular diseases. Circulation Journal: Circ J 2009; 73(2): 201-207.

[57] Valko M, Leibfritz D, Moncol J, Cronin MTD, Mazur M, Telser J. Free radicals and antioxidants in normal physiological functions and human disease. Int J Biochem Cell Biol 2007; 39(1): 44-84.

[58] Ceriello A. Possible role of oxidative stress in the pathogenesis of hypertension. Diabetes Care 2008; 31(Supplement 2): S181-S184.

[59] Montezano A \& Touyz RM. Reactive oxygen species, vascular Noxs and hypertension: Focus on translational and clinical research. Antioxid Redox Signal 2013; doi: 10.1089/ars.2013.5302.

[60] Vaziri ND, Wang XQ, Oveisi F, Rad B. Induction of oxidative stress by glutathione depletion causes severe hypertension in normal rats. Hypertension 2000; 36(1): 142-146.

[61] Mansego ML, Solar GDM, Alonso MP, Martínez F, Sáez GT, Escudero JCM, Redón J, Chaves FJ. Polymorphisms of antioxidant enzymes, blood pressure and risk of hypertension. J Clin Hypertens 2011; 29(3): 492-500.

[62] Hsueh Y, Lin P, Chen H, Shiue H, Chung C, Tsai C, Huang Y, Chiou H, Chen C. Genetic polymorphisms of oxidative and antioxidant enzymes and arsenic-related hypertension. J Toxicol Environ Health 2005; Part A, 68(17-18): 1471-1484.

[63] Guzik TJ, Hoch NE, Brown KA, McCann LA, Rahman A, Dikalov S, Goronzy J, Weyand C, Harrison DG. Role of the T cell in the genesis of angiotensin II-induced hypertension and vascular dysfunction. J Exp Med 2007; 204(10): 2449-2460.

[64] Cheung BM, Ong KL, Tso AW, Leung RY, Cherny SS, Sham PC, Thomas GN, Lam $\mathrm{TH}$, Lam KS. Relationship of plasma interleukin-6 and its genetic variants with hypertension in Hong Kong Chinese. Am J Hypertens 2011; 24(12): 1331-1337. 
[65] Hlebowicz J, Persson M, Gullberg B, Sonestedt E, Wallström P, Drake I, Nilsson J, Hedblad B, Wirfält E. Food patterns, inflammation markers and incidence of cardiovascular disease: the Malmö Diet and Cancer study. J Intern Med 2011; 270(4): 365-376.

[66] Lob HE, Marvar PJ, Guzik TJ, Sharma S, McCann LA, Weyand C, Gordon FJ, Harrison DG. Induction of hypertension and peripheral inflammation by reduction of extracellular superoxide dismutase in the central nervous system. Hypertension 2010; 55(2): 277-283.

[67] McIntyre M, Bohr DF, Dominiczak AF. Endothelial Function in Hypertension The role of superoxide anion. Hypertension 1999; 34(4): 539-545.

[68] Landmesser U, Dikalov S, Price SR, McCann L, Fukai T, Holland SM, Mitch WE, Harrison DG. Oxidation of tetrahydrobiopterin leads to uncoupling of endothelial cell nitric oxide synthase in hypertension. J Clin Invest 2003; 111(8): 1201-1209.

[69] Harrison D, Widder J, Grumbach I, Chen W, Weber M, Searles C. Endothelial mechanotransduction, nitric oxide and vascular inflammation. J Intern Med 2006, 259(4): 351-363.

[70] Harrison DG. Oxidative stress and vascular inflammation. In G. Hoffman, C. Weyand, C. Langford, J. Goronzy (Eds.). Inflammatory diseases of blood vessels (2nd ed.), John Wiley and Sons; 2012. p94-104.

[71] Veliotes DG, Norton GR, Correia RJ, Strijdom H, Badenhorst D, Brooksbank R, Woodiwiss AJ. Impact of aldosterone receptor blockade on the deleterious cardiac effects of adrenergic activation in hypertensive rats. J Cardiovasc Pharmacol 2010; 56(2): 203-211.

[72] Abu-Ghefreh A, Khan I. A role of intestine in hypertension: mechanism of suppression of intestinal $\mathrm{Na}-\mathrm{H}$ exchanger isoform-3 in spontaneously hypertensive rats. Clin Exp Hypertens 2013; 35(7):543-549.

[73] Quintana-Villamandos B, Delgado-Martos MJ, Sánchez-Hernández JJ, Gómez de Diego JJ, Fernández-Criado Mdel C, Canillas F, Martos-Rodríguez A, Delgado-Baeza E. Early regression of left ventricular hypertrophy after treatment with esmolol in an experimental rat model of primary hypertension. Hypertens Res 2013; 36: 408-413.

[74] Cutler JA. Calcium-channel blockers for hypertension: uncertainty continues. N Engl J Med 1998; 338(10): 679-681.

[75] Blood Pressure Lowering Treatment Trialists'Collaboration. Effects of ACE inhibitors, calcium antagonists, and other blood-pressure-lowering drugs: results of prospectively designed overviews of randomised trials. Lancet 2000; 355(1): 955-964.

[76] Guzman-Uriarte ML, Sánchez-Magaña LM, Angulo-Meza GY, Cuevas-Rodríguez EO, Gutiérrez-Dorado R, Mora-Rochín S, Milán-Carrillo J, Valdez-Ortiz A, ReyesMoreno C. Solid state bioconversion for producing common bean (Phaseolus vulgaris 
L.) Functional flour with high antioxidant activity and antihypertensive potential. Food Nutr (Roma) 2013; 4: 480-490.

[77] Asase A, Oteng-Yeboah AA, Odamtten GT, Simmonds MS. Ethnobotanical study of some Ghanaian anti-malarial plants. J Ethnopharmacol 2005; 99(2): 273-279.

[78] Osho I \& Lajide L. Prescreening evaluation of some plant extracts used in ethno-veterinary practices as antitrypanosomal agents. J Med Plant Res 2012; 6(11): 2056-2060.

[79] Luckow M \& Hopkins HC. A cladistic analysis of Parkia (Leguminosae: Mimosoideae). Am J Bot 1995; 82(10): 1300-1320.

[80] Adaramola T, Ariwaodo J, Adeniji K. Distribution, Phytochemistry and Antioxidant Properties of the Genus Parkia R. br.(Mimosaceae) in Nigeria. IJPPR 2013; 4(4), 172-178.

[81] Teklehaimanot Z. Exploiting the potential of indigenous agroforestry trees: Parkia biglobosa and Vitellaria paradoxa in sub-Saharan Africa. Agroforest Syst 2004; 61: 207-220.

[82] World Agroforestry centre. n.d. Parkia biglobosa. http://www.worldagroforestry.org/ treedb2/speciesprofile.php?Spid=1255. [June 2013].

[83] Sina S \& Traoré SA. Parkia biglobosa (Jacq.) R.Br. ex G.Don. [Internet] Record from PROTA4U. Oyen, L.P.A. \& Lemmens, R.H.M.J. (Editors). PROTA (Plant Resources of Tropical Africa / Ressources végétales de l'Afrique tropicale) 2002, Wageningen, Netherlands. http://www.prota4u.org/search.asp (accessed 23 August 2013).

[84] Ajaiyeoba EO. Phytochemical and antibacterial properties of Parkia biglobosa and Parkia bicolor leaf extracts. AJBR 2003; 5(3): 125-129.

[85] Udobi C \& Onaolapo J. Phytochemical analysis and antibacterial evaluation of the leaf stem bark and root of the African locust bean (Parkia biglobosa). J Med Plant Res 2009; 3(5): 338-344.

[86] Millogo-Kone H, Guissou I, Nacoulma O, Traore A. Antimicrobial effects of the stem bark extracts of Parkia biglobosa (jacq.) Benth. on Shigellae. Afr J Tradit Complement Altern Med 2008; 4(4): 392-396.

[87] Komolafe K, Akinmoladun AC, Olaleye TM. Methanolic leaf extract of Parkia biglobosa protects against doxorubicin-induced cardiotoxicity in rats. IJARNP 2013; 6(3): 39-47.

[88] Tala VRS, Candida da Silva V, Rodrigues CM, Nkengfack AE, Campaner dos Santos L, Vilegas W. Characterization of Proanthocyanidins from Parkia biglobosa (Jacq.) G. Don.(Fabaceae) by Flow Injection Analysis-Electrospray Ionization Ion Trap Tandem Mass Spectrometry and Liquid Chromatography/Electrospray Ionization Mass Spectrometry. Molecules 2013; 18(3): 2803-2820. 
[89] Koura K, Ganglo JC, Assogbadjo AE, Agbangla C. Ethnic differences in use values and use patterns of Parkia biglobosa in northern Benin. J Ethnobiol Ethnomed 2011; $7: 42$.

[90] Tapsoba H, Deschamps J. Use of medicinal plants for the treatment of oral diseases in Burkina faso. J Ethnopharmacol 2006; 104(1):68-78.

[91] Ménan H, Banzouzi J, Hocquette A, Pélissier Y, Blache Y, Koné M, Mallié M, Assi LA, Valentin A. Antiplasmodial activity and cytotoxicity of plants used in West African traditional medicine for the treatment of malaria. J Ethnopharmacol 2006; 105(1): 131-6.

[92] Inngjerdingen K, Nergård CS, Diallo D, Mounkoro PP, Paulsen BS. An ethnopharmacological survey of plants used for wound healing in Dogonland, Mali, West Africa. J Ethnopharmacol 2004; 92(2):233-44.

[93] Nordeng H, Al-Zayadi W, Diallo D, Ballo N, Paulsen BS. Traditional medicine practitioners' knowledge and views on treatment of pregnant women in three regions of Mali. J Ethnobiol Ethnomed 2013; 9(1):67.

[94] Lehman AD, Dunkel FV, Klein RA, Ouattara S, Diallo D, Gamby KT, N’Diaye M. Insect management products from Malian traditional medicine-Establishing systematic criteria for their identification. J Ethnopharmacol 2007; 110(2):235-249.

[95] Abubakar M, Musa A, Ahmed A, Hussaini I. The perception and practice of traditional medicine in the treatment of cancers and inflammations by the Hausa and Fulani tribes of northern Nigeria. J Ethnopharmacol 2007; 111(3):625-629.

[96] Agunu A, Yusuf S, Andrew GO, Zezi AU, Abdurahman EM. Evaluation of five medicinal plants used in diarrhoea treatment in Nigeria. J Ethnopharmacol 2005; 101(1): 27-30.

[97] Adetutu A, Winston MA, Corcoran O, Chimezie F. Antibacterial activity and in vitro cytotoxicity of extracts and fractions of Parkia biglobosa (Jacq.) Benth stem bark and Ageratum conyzoides Linn. leaves. Environ Toxicol Pharmacol 2012; 34: 478-483.

[98] Lawal I, Uzokwe N, Igboanugo A, Adio A, Awosan E, Nwogwugwu J, Faloye B, Olatunji B, Adesoga A. Ethno medicinal information on collation and identification of some medicinal plants in research institutes of South-West Nigeria. AJPP 2010; 4(1): $1-7$.

[99] Erakhrumen A, Ogunsanwo O, Ajewole O. Assessment of some other traditional uses of accepted agroforestry fuelwood species in Akinyele and Ido local government areas, Oyo state, Nigeria. IJSF 2010; 3(1):47-65.

[100] Tchacondo T, Karou SD, Batawila K, Agban A, Ouro-Bang'na K, Anani KT, Gbeassor $\mathrm{M}$, de Souza C. Herbal remedies and their adverse effects in tem tribe traditional medicine in Togo. Afr J Tradit Complement Altern Med 2011; 8(1):45-60. 
[101] Adi K, Metowogo K, Mouzou A, Lawson-Evi P, Eklu-Gadegbeku K, Agbonon A, Lamboni C, Essien K, Aklikokou K, Gbeassor M. Evaluation of cardioprotective effects of Parkia biglobosa (jacq. benth) Mimosaceae stem bark. J App Pharm Sci 2013; 3(02):060-4.

[102] Kouadio F, Kanko C, Juge M, Grimaud N, Jean A, N'guessan Y, Petit J. Analgesic and antiinflammatory activities of an extract from Parkia biglobosa used in traditional medicine in the Ivory Coast. Phytother Res 2000; 14(8): 635-637.

[103] Asuzu I \& Harvey A. The antisnake venom activities of Parkia biglobosa (Mimosaceae) stem bark extract. Toxicon 2003; 42(7): 763-768.

[104] El-Mahmood A \& Ameh J. In vitro antibacterial activity of Parkia biglobosa (Jacq.) root bark extract against some microorganisms associated with urinary tract infections. Afr J Biotechnol 2007; 6(11): 1272-1275.

[105] Builders M, Wannang N, Aguiyi J. Antiplasmodial activities of Parkia biglobosa leaves: In vivo and In vitro studies. Ann Biol Res 2011; 2(4): 8-20.

[106] Lamien-Meda A, Lamien CE, Compaoré MM, Meda RN, Kiendrebeogo M, Zeba B, Millogo JF, Nacoulma OG. Polyphenol content and antioxidant activity of fourteen wild edible fruits from Burkina Faso. Molecules 2008; 13(3): 581-594.

[107] Nwaehujor C, Ezeigbo I, Udeh N, Asuzu I. Anti-inflammatory and anti-oxidant activities of the methanolic extracts of the stalk of Parkia biglobosa (JACQ.) BENTH. Hygeia J D Med 2011; 8: 34-40.

[108] Xu H, Yu X, Qu S, Chen Y, Wang Z, Sui D. In vivo and in vitro cardioprotective effects of Panax quinquefolium 20 (S)-protopanaxadiol saponins (PQDS), isolated from Panax quinquefolium. Die Pharmazie-An Int J Pharm Sci 2013; 68(4): 287-292.

[109] Xie J, Dial LD, Shapiro JI. Na/K-ATPase signaling and the tradeoff between natriuresis and cardiac fibrosis.In cardiomyopathies, Milei, J. (Ed.) InTech, DOI: 10.5772/54722; 2013.

[110] Zou B, Li C, Chen J, Dong X, Zhang Y, Du J. High molecular weight persimmon tannin is a potent hypolipidemic in high-cholesterol diet fed rats. Food Res Int 2012; 48(2): 970-977.

[111] Fan $H$, Wu D, Tian W, Ma X. Inhibitory effects of tannic acid on fatty acid synthase and 3T3-L1 preadipocyte. BBA- Molecular and Cell Biology of Lipids 2013; 1831(7): 1260-1266.

[112] Sudharsan P, Mythili Y, Selvakumar E, Varalakshmi P. Cardioprotective effect of pentacyclic triterpene, lupeol and its ester on cyclophosphamide-induced oxidative stress. Hum Exp Toxicol 2005; 24(6): 313-318. 
[113] Sudhahar V, Kumar SA, Sudharsan PT, Varalakshmi P. Protective effect of lupeol and its ester on cardiac abnormalities in experimental hypercholesterolemia. Vascul Pharmacol 2007, 46(6): 412-418.

[114] Miura, Y., Chiba, T., Tomita, I., Koizumi, H., Miura, S., Umegaki, K., Hara, Y. \& Ikeda, M. 2001. Tea catechins prevent the development of atherosclerosis in apoprotein E-deficient mice. J Nutr, 131(1): 27-32.

[115] Shah, Z.A., Li, R., Ahmad, A.S., Kensler, T.W., Yamamoto, M., Biswal, S. \& Doré, S. 2010. The flavanol (-)-epicatechin prevents stroke damage through the Nrf2/HO1 pathway. J Cereb Blood Flow Metab, 30(12): 1951-1961.

[116] Flammer, A.J., Sudano, I., Wolfrum, M., Thomas, R., Enseleit, F., Périat, D., Kaiser, P., Hirt, A., Hermann, M. \& Serafini, M. 2012. Cardiovascular effects of flavanol-rich chocolate in patients with heart failure. Eur Heart J, 33(17): 2172-2180.

[117] Tokoudagba, J., Auger, C., Bréant, L., N'Gom, S., Chabert, P., Idris-Khodja, N., Gbaguidi, F., Gbenou, J., Moudachirou, M., Lobstein, A. 2010. Procyanidin-rich fractions from Parkia biglobosa (Mimosaceae) leaves cause redox-sensitive endothelium-dependent relaxation involving $\mathrm{NO}$ and EDHF in porcine coronary artery. J Ethnopharmacol, 132(1): 246-250. 
